\title{
Modeling the Propensity to Default on Microloans in Mali, Africa
}

\author{
JULIA R. NORGAARD \\ George Mason University
}

\begin{abstract}
Microfinance is a global phenomenon that is focused on sustainable poverty alleviation. By providing people in developing countries with the capital to sustain themselves and an educational background on which to build their futures, microfinance institutions (MFIs) give the poor an opportunity to get out of poverty. This study utilized a specific MFI in Mali, Africa to model the propensity for borrowers to default on microloans. Using the MFI's historical data, the purpose of this study is to model the repayment percentage of individual loans, contingent upon qualitative and quantitative factors. An Ordinary Least Squares Model is used to analyze how each independent factor influences default rates. Factors that contribute to high default rates are grouped together using fuzzy analysis. I hypothesize that high default rates were encouraged by a longer time between payments, a large initial loan size, development of business in investment-heavy industries, and in a hostile market environment. These results indicate that the MFI can optimize its loan repayment success by targeting specific borrowers and modifying their loan structure. The results of this study suggest tangible practices the Mali MFI can utilize to increase their loaning effectiveness.
\end{abstract}

\section{Introduction}

Microfinance is a global phenomenon that is focused on sustainable poverty alleviation. By providing people in developing countries with the capital to sustain themselves and an educational background on which to build their futures, microfinance institutions (MFIs) have given the poor an opportunity to get out of poverty. These loans are un-collateralized and thus depend on character-based lending. MFIs strive to decrease poverty in their location of business, so they focus on reaching out to the poor who have entrepreneurial potential. In the developing world, sound financial institutions are difficult to come by, and those that do exist require high 
credit scores and collateral for loans. Microfinance seeks to combat this structural disadvantage of the poor by providing them with the means to succeed in a small business (Grameen Bank, 2012).

Mali is a vibrant country, however, it suffers from extreme poverty. Mali is one of the 10 poorest countries in the world; their GDP per capita in US dollars is \$531 (Central Intelligence Agency, n.d.) Historically, MFIs evidence some common trends; for example, about $80 \%$ of worldwide microloans are given to women due to their superior repayment history and their dedication to improving their families with the money they earn. Many MFIs also utilize group loans to increase repayment rates because of the peer pressure and social compulsion to repay the loans. These group-lending MFIs boast about a 96\% worldwide repayment rate (CGAP, n.d.) The Mali MFI data analyzed in this study represent some group loans, but most are individual loans.

The Mali MFI is small and new to the microfinancing world. It is, therefore, important that they collect and analyze data to improve their repayment rate performance and their effectiveness in helping the poor. Much of the literature dedicated to microfinance does not analyze default rates and there is a lack of microfinance study in Mali. Fuzzy analysis has also never been utilized to investigate grouped factors that impact default rates. Kurosako and Khan (2012) studied default rates for microloans in Pakistan and observed that default rates have high explanatory power in the success of joint liability loans among the poor (p. 83). Consistent with economic theory, Pande and Field (2008) found that a more lenient repayment schedule lowers transaction costs and does not increase default rates (p. 510).

This study adds to the existing literature by modeling the repayment percentage of individual loans, contingent upon personal and monetary factors. The literature suggests that certain institutional rigidities of microfinance markets held them back in the past from reaching their full potential for poverty alleviation (Hertz-Bunzl, 2006; Kaladhar, 1997). Certain design features of the lending process could be changed to ensure more borrower success (Kaladhar, 1997). This study looks specifically at what those rigidities and design features could be. The economics and microfinance literature supports the notion that microfinance can be a key component in poverty alleviation, specifically for women and people in developing nations (Khandker, 2005). 
An Ordinary Least Squares (OLS) Model is used to analyze the influence of independent factors on default rates. This method is ideal for analyzing various rigidities within this specific micro-lending framework, whether it be that the loans are too large, the interest rate is too high, or the type of businesses they are supporting are unsuccessful. Fuzzy analysis is used to group together factors that contribute to high default rates as a collective. This is a powerful type of analysis used to identify the significance of groups of variables rather than individual variables. In the current study, fuzzy analysis allows for the analysis of groups of variables that can support suggestions for improvement of default rate by changing many variables rather than just one. The hypothesis in this study is that high default rates are encouraged by a longer time between payments, a large initial loan size, business development in investment-heavy industries, and starting a business in a hostile market environment. The purpose of this study is to provide the Mali MFI with tangible results it can utilize to increase its loan effectiveness.

\section{Theoretical Issues of Microfinance Studies}

Microfinance is a relatively new field and the formal literature surrounding it is new and growing. Microfinanciers have tailored their loan style to specific groups and to meet the needs

of the poor in the geographical area in question. Through trial-and-error, as well as through knowledge of poverty, MFIs have developed what lenders think will best meet the needs of these borrowers. Data collected by MFIs reveal trends that suggest certain groups and loan styles will be more successful with microloan borrowing than others, and formal research indicates that some of these suggested practices have statistical significance (Balasubramanian, 2009; Hermes \& Lensink, 2007; Kaladhar, 1997). Many microfinance institutions feel they have to walk a fine line by providing community development programs and financial services (Hermes \& Lensink, 2007; Vanroose, 2008).

Over $80 \%$ of worldwide micro-borrowers are women. Microfinance institutions have observed that women micro-borrowers are successful in helping their families because they spend their money on investing in their future and those of their children. Statistically, women more than men spend their profits on education for their children, healthcare, and infrastructure for their houses (Opportunity International, n.d.). These findings suggest that microfinance loans may be more successful when given to women (Leach \& Sitaram 2002; Vonderlack \& Schreiner, 2002). 
Because many micro-borrowers have no previous experience with borrowing money, many practitioners suggest that having strict repayment schedules will help the borrowers develop fiscal responsibility by constantly holding them accountable for repaying their loans. Some suggest that 1-2 weeks between payment periods is not too frequent because borrowers make their loan more of a priority in their life meet with their loan officer or loan group more often (Grameen Bank, 2012). There is also extensive research that supports the MFI provision of regular repayment schedules because they act as effective enforcement mechanisms for loan repayment (Besley, 1995; Morduch, 1999; Morvant, 2007). However, some empirical studies have shown the opposite. For example, Pande and Field (2008) found that a more flexible repayment schedule does not increase default rates and actually leads to decreased transaction costs.

Economic theory suggests that collateralized loans ensure more successful loan repayment rates because the cost of defaulting on collateralized loans is much higher (Becchetti \& Pisani, 2010). Therefore, many MFIs have incorporated a type of "cultural collateral" which is known as microfinance group lending. Groups are held collectively accountable for the repayment of their loans and their relationships among each other act as their loan collateral. The Grameen Bank has championed worldwide group micro-lending and suggests that group loans are the best way to ensure repayment and community involvement (Grameen Bank, 2012). This study tests which loan factors impact default rates for Mali MFI loans.

\section{Data and Variables}

Data were collected over a period of four years by an MFI in Mali, Africa. The data consist of 84 micro-borrowers and 111 individual loans. These loans spanned from just a few years to multiple months, there was detailed information about the timeliness of repayment as well as borrower characteristics. These data are from various locations in Mali and numerous types of businesses. The 84 borrowers represent 11 different ethnicities in Mali and 10 Malian cities, primarily in the central and the southwestern regions of Mali. Borrowers are mostly individual males and females, although some group loans are included. The borrowers comprise varied religious identities, including Protestant, Catholic, and Muslim, and their businesses include food service and clothing retail, animal husbandry, and solar oven construction. Various loan-specific variables included in the data are: status of the loan, loan principal, interest rate, 
amount overdue, amount of loan outstanding, amount written off (an amount that the MFI does not expect to receive back, typically due to an emergency situation), number of late and early payments, and the default rate (the dependent variable). The data also include whether or not there was violence in the marketplace during the period of the loan.

\section{Summary Statistics}

The summary statistics in Table $1^{1}$ represent the significant variables that are included in the final model. The most statistically significant variables include "Location 4," which makes up $12 \%$ of the loan population; "Muslim," which makes up $7 \%$ of the loan population; and "Other Businesses," which includes 9\% of the sample population. All of the statistically significant variables are dummy variables. If the loan has that characteristic, it has a 1 in the dummy variable column; if it does not have that characteristics, it has a 0 .

\section{Method}

\section{Ordinary Least Squares}

The statistical software package STATA was utilized to analyze this data set. These data were collected from an internal MFI source that is not available to the public; they were collected and formatted into a cross-sectional data set.

An OLS model is used to analyze the contributing factors to default rate. Analyzing both quantitative and qualitative specifics to each loan, the OLS model is:

$$
\begin{gathered}
\mathrm{Y}_{i}=\alpha+\beta \mathrm{CLW}_{i}+\gamma \mathrm{CLM}_{i}+\delta \mathrm{A}_{i}+\eta \mathrm{IP}_{i}+\varphi \mathrm{LO}_{i}+\theta \mathrm{ETH}_{i}+\psi \mathrm{LOB}_{i}+\rho \mathrm{RE}_{i}+\sigma \mathrm{RST}_{i}+ \\
\kappa \mathrm{GEN}_{i}+\lambda \mathrm{GR}_{i}+\varsigma \mathrm{BUS}_{i}+\mu_{i}
\end{gathered}
$$

Where $\alpha$ is the intercept; CLW is whether or not the loan was closed and written off; CLM is whether or not the loan was closed and the obligations of the loan were met; A is whether or not the loan is active; IP is the set of varying interest and principle variables; LO is the set of office location variables; ETH is the set of ethnicity variables; LOB is the set of location of business variables; RE is the set of religion variables; RST is the set of relationship to the staff member variables; GEN is the set of gender variables; GR is whether or not the loan is a group loan; BUS is the set of business type variables; and $\mu_{i}$ is the error term. For purposes of this study, the natural log was calculated for every variable that was originally measured in

\footnotetext{
${ }^{1}$ All tables are located in the Appendix.
} 
African Francs (principal of loan, amount written off, amount paid) to better assess the impact of the variable.

OLS regression analysis is used to examine the dependent variable - the default rate for each individual loan (Y). All of the variables that are in groups were tested for their group significance using a test of the null hypothesis that all variables are 0 .

\section{Fuzzy Analysis}

Fuzzy-set analysis is also utilized to analyze these data. Fuzzy-set is a qualitative comparative analysis (QCA) that is a powerful new way to analyze multivariate data (Longest \& Vaisey, 2008). QCA harnesses the power of Boolean logic to assess the correlation between the dependent variable, the default rate of each individual loan, and all binary combinations of multiple independent variables. This analysis provides specific combinations of independent variables that offer evidence that there are various pathways to reach certain outcomes. The inclusion ratio is used to evaluate the relationships in question:

$$
I_{\mathrm{XY}}=\Sigma \min \left(x_{i}, y_{i}\right) / \Sigma x_{i}
$$

In fuzzy analysis, $\mathrm{X}$ is the predictor configuration, $\mathrm{Y}$ is the outcome set, $x_{i}$ is each variable's place in the configuration of $\mathrm{X}$, and $y_{i}$ is each variable's place in the configuration of $\mathrm{Y}$. The closer $I_{\mathrm{XY}}$ is to unity, the larger the consistency of the data with the statement "if $\mathrm{X}$, then Y" (Longest \& Vaisey, 2008). Each solution is then analyzed with respect to its coverage of the outcome. This coverage indicator measures how much of $\mathrm{Y}$ is covered by $\mathrm{X}$ :

$$
\mathrm{C}_{\mathrm{XY}}=\Sigma \min \left(x_{i}, y_{i}\right) / \Sigma x_{i}
$$

The coverage indicator calculates how much of the outcome is explained by examining the final solution set. Longest and Vaisey (2008) summarize the capacity of fuzzy-set analysis:

the fuzzy program allows the user to create configurations from single sets coded as dichotomous or fuzzy, to evaluate the sufficiency of these configurations statistically by using a variety of benchmarks, and to reduce the configurations determined sufficient to their common logical elements. (p. 83)

I employ fuzzy-set analysis to examine the impact of groups of variables on the default rates. 


\section{Results}

Analysis of all qualitative and quantitative variables pertaining to each individual loan indicates that many quantitative variables are insignificant $(\mathrm{p}>.10)$ in determining default rate. Quantitative variables include variables such as loan amount, interest rate, and loan duration. Qualitative variables include variables such as religion, location, type of business, and personal characteristics (Cassar \& Wydick, 2010; Gine, 2007). Many of the variables discussed in the theoretical section of this paper are found to be insignificant, such as loan amount, thus making it difficult to comment on the existing theory of micro-lending. This is most likely due to the fact that the sample size is small with only 111 observations.

Significant variables identified in the model include status of the loan, location of the business, religion of the borrower, group loan, and type of business. All of the groups of variables were found, after statistical testing, to have noteworthy group significance. The "status of loan" group variables are compared to the "written off closed loan" variable that was not included in the model. All of the location variables are compared to location 8 (the exact locations cannot be disclosed because of non-disclosure agreement stipulations). The religion variables are compared to the Catholic variable, which is not included in the model. The significance of this type of social capital is supported by the literature (Cassar \& Wydick, 2010). The "type of business" variables are compared to the animal husbandry variable that is also not included in the model. The OLS model explains $69.6 \%$ of the variation in the data; this could also be due to the fact that there are a large number of variables in the model. Although this comprehensive data set included a great deal of variables, there were many things that were not included in the data that could have influenced the variation in the data such as previous business experience and/or business help from family.

The regression results of the statistically significant variables indicate that any loan status, other than "written off closed loan," contributes to a lower default rate significantly. Importantly, loans to a micro-business in Location 4 have a $27 \%$ higher default rate than businesses in Location 8. Location 4 was the site of market raids that destroyed many of the marketplaces where micro-borrowers sold their goods. Market conditions in Location 4 were unstable and dangerous, which likely contributed to borrowers defaulting on their loans (James, Nadarajah, Haive, \& Stead, 2012). 
According to the results, group loans also had high default rates. Group loans were 23\% more likely to be in default than individual loans, which is significant at the $p<.05$ level. This is an interesting finding because it runs counter to the advice of microfinance practitioners. Much research supports the notion that group lending creates a joint liability with loan repayment which, in turn, reduces information asymmetries (Hermes \& Lensink, 2007). One explanation as to why group borrowers have a more difficult time repaying their loans is because this MFI in Mali caters primarily to individual borrowers. This specific MFI only takes on a few group loans, suggesting the MFI may not be tailoring their lending practices to group needs.

The "Muslim" variable is very significant; its coefficient shows that, if the microborrower is Muslim, they will have a 22\% higher default rate than Catholic borrowers. This finding is consistent with the theory that Muslim borrowers may have a more difficult time with microloans because of religious practices regarding "interest-free" loans (Seibel, 2008). Another significant variable is "Food Retail." Compared to "Animal Husbandry," food retail businesses are $20 \%$ less likely to default on their loans. The regression results shed interesting light on what kinds of factors contribute to successful loan repayment rates for this MFI.

Fuzzy analysis was used for the grouped variables to determine the impact on the dependent variable of each variable group combination. The following "paths" identify combinations found to be conditions for low default rates. The first path is: if the loan is not given in Location 4, the borrower is not Muslim, it is not a group loan, and is not given to a business of type "other," then the default rate is low. The second path to low default rates is: if the loan is not given in Location 4, the micro-borrower is not Muslim, the loan is not a group loan, and the business is in the "other" business. The third path is: if the loan is not given in Location 4, the micro-borrower is Muslim, the loan is not a group loan, and the business is not from the "other" category, then the loan default rate is low. The last path is: if the loan is not from Location 4, the borrower is not Muslim, the loan is a group loan, and it is not from the "other" business category, then the loan default rate is low. These paths make up combinations of significant variables and if a loan follows one of these paths, the loan will be less likely to end in default.

\section{Regression Results}

Table 2 shows the regression results for OLS model. This model includes the coefficient of each variable and their standard errors. A negative coefficient means that the variable 
contributes to a lower default rate. Variables that contribute to a lower default rate include obligation met, overpaid, active, location 1, location 4, Muslim, group loan, retail business, and other business.

\section{Fuzzy Results}

Table 3 displays the various fuzzy outputs and their significance. Each set is labeled with its path number. It appears that all of these combinations are significant. The four combinations are:

1: Location 4, Muslim, Group Loan, Other Business

2: Location 4, Muslim, Group Loan

3: Location 4, Group Loan, Other Business

4: Location 4, Muslim, Other Business

Each of these paths represents a combination of significant variables and how they contribute to the dependent variable as a group. Table 4 shows the various combinations of variables that make up conditions for a low default rate.

\section{Conclusions}

This study determined that there are numerous factors that are correlated with loan repayment rates in Mali, Africa; significant variables include obligation met, overpaid, active, location 1, location 4, Muslim, group loan, retail business, and other business. Because these variables are statistically significantly correlated with repayment rates, this suggests that microlenders could increase their borrower's lending success by encouraging them to pursue certain types of businesses (retail and other businesses) or focus on more successful areas to lend to (location 1 and location 4). The most significant contributing factors were not the quantitative variables, but the qualitative independent variables. The final model explains $69.6 \%$ of the variation in the data. The knowledge gained by this study may aid the Mali MFI in tailoring their loans in a more effective manner to increase their repayment percentage.

Study limitations include the scope and time frame of this study. Although the model explains $69.9 \%$ of the variation in the default rates, the data are from a small sample size. Additionally, the data for this study were collected over a short period of time from only one MFI. A cross-sectional study from many MFIs would yield more robust results, and data collected over a longer time period would benefit the implications of this study. Future studies 
may enable the Mali MFI to further their investigation in success metrics for the impact of micro-loans on poverty. 


\section{References}

Balasubramanian, A. (2009). Micromanagement: Fixing microfinance in Argentina. Harvard International Review, 31(3), 9-10. Retrieved from http://www.jstor.org/stable/42763311

Becchetti, L., \& Pisani, F. (2010). Microfinance, subsidies and local externalities. Small Business Economics, 34, 309-321. http://dx.doi.org/10.1007/s11187-008-9125-y

Besley, T. (1995). Non-market institutions for credit and risk sharing in low-income countries. Journal of Economic Perspectives, 9(3), 115-127. http://dx.doi.org/10.1257/jep.9.3.115

Cassar, A., \& Wydick, B. (2010). Does social capital matter? Evidence from a five-country group lending experiment. Oxford Economic Papers, 62, 715-739. http://dx.doi.org/10.1093/oep/gpq010

Central Intelligence Agency. (n.d.). Mali, Africa. Retrieved from https://www.cia.gov/library/publications/the-world-factbook/geos/ml.html

Consultative Group to Assist the Poor (CGAP). (n.d.). What is Microfinance? Retrieved from http://www.cgap.org/about/faq/what-microfinance

Gine, X. (2007). Why does access matter?: Impact on growth and poverty. In M. S. Barr, A. Kumar, \& R. E. Litan (Eds.), Building inclusive financial systems: A framework for financial access (pp. 33-56). Retrieved from http://www.jstor.org/stable/10.7864/j.ctt12624b.6

Grameen Bank. (2012, March 2). What is microcredit? Retrieved from http://www.grameeninfo.org/what-is-microcredit/

Hermes, N., \& Lensink, R. (2007). The empirics of microfinance: What do we know?. Economic Journal, 117, F1-F10. http://dx.doi.org/10.1111/j.1468-0297.2007.02013.x

Hertz-Bunzl, N. (2006). Financing hope: Improving microfinance. Harvard International Review, 27(4), 32-34. Retrieved from http://www.jstor.org/stable/42763052

James, P., Nadarajah, Y., Haive, K, \& Stead, V. (2012). Microfinance and community development. In Sustainable communities, sustainable development: Other paths for Papua New Guinea (pp. 247-279). Retrieved from http://www.jstor.org/stable/j.ctt6wqgh2.12

Kaladhar, K. (1997). Microfinance in India: Design, structure and governance. Economic and Political Weekly, 32, 2687-2706. Retrieved from http://www.jstor.org/stable/4405979

Khandker, S. R. (2005). Microfinance and poverty: Evidence using panel data from Bangladesh. World Bank Economic Review, 19, 263-286. Retrieved from http://www.jstor.org/stable/40282216 
Kurosako, T., \& Khan, H. U. (2012). Vulnerability of microfinance to strategic default and covariate shocks: Evidence from Pakistan. Developing Economies, 50, 81-115. http://dx.doi.org/10.1111/j.1746-1049.2012.00160.x

Leach, F., \& Sitaram, S. (2002). Microfinance and women's empowerment: A lesson from India. Development in Practice, 12, 575-588. http://dx.doi.org/10.1080/0961452022000017597

Longest, K. C., \& Vaisey, S. (2008). Fuzzy: A program for performing qualitative comparative analyses (QCA) in Stata. Stata Journal, 8, 79-104. Retrieved from http://www.statajournal.com/

Morduch, J. (1999). The microfinance promise. Journal of Economic Literature, 37, 1569-1614. Retrieved from https://www.aeaweb.org/journals/jel

Morvant, S. (2007). MFI's clients borrowing strategies and lending groups financial heterogeneity under progressive lending: Evidence from rural Mexico. Savings and Development, 31, 193-216. Retrieved from http://www.jstor.org/stable/25830960

Opportunity International. (n.d.). Microfinance for global entrepreneurs. Retrieved from http://opportunity.org/what-we-do/microfinance

Pande, R., \& Field, E. (2008). Repayment frequency and default in microfinance: Evidence from India. Journal of the European Economic Association, 6, 501-509. http://dx.doi.org/10.1162/jeea.2008.6.2-3.501

Seibel, H. D. (2008). Islamic microfinance in Indonesia: The challenge of institutional diversity, regulation, and supervision. Sojourn: Journal of Social Issues in Southeast Asia, 23, 86103. http://dx.doi.org/10.1355/sj23-1d

Vanroose, A. (2008). What macro factors make microfinance institutions reach out? Savings and Development, 32, 153-174. Retrieved from http://www.jstor.org/stable/41406468

Vonderlack, R. M. \& Schreiner, M. (2002). Women, microfinance, and savings: Lessons and proposals. Development in Practice, 12, 602-612. Retrieved from http://www.jstor.org/stable/4029405 


\section{Appendix}

Table 1

MFI Loan Summary Statistics

\begin{tabular}{|c|c|c|c|c|c|c|}
\hline Variable Name & Variable Description & Count & Average & $\begin{array}{l}\text { Standard } \\
\text { Deviation }\end{array}$ & Minimum & Maximum \\
\hline clsd_writtenoff & $\begin{array}{l}\text { Closed and written off } \\
\text { loan }\end{array}$ & 28 & 0.25 & 0.44 & 0 & 1 \\
\hline clsd oblmet & $\begin{array}{l}\text { Closed loan with } \\
\text { obligations met }\end{array}$ & 35 & 0.32 & 0.47 & 0 & 1 \\
\hline overpaid & Overpaid loan & 17 & 0.15 & 0.36 & 0 & 1 \\
\hline active & Acrive Loan & 31 & 0.28 & 0.45 & 0 & 1 \\
\hline 10_1 & Location 1 & 15 & 0.14 & 0.34 & 0 & 1 \\
\hline $10 \_2$ & Location 2 & 11 & 0.10 & 0.30 & 0 & 1 \\
\hline $10 \_3$ & Location 3 & 33 & 0.30 & 0.46 & 0 & 1 \\
\hline 10 & Location 4 & 13 & 0.12 & 0.32 & 0 & 1 \\
\hline $10 \_5$ & Location 5 & 5 & 0.05 & 0.21 & 0 & 1 \\
\hline 106 & Location 6 & 20 & 0.18 & 0.39 & 0 & 1 \\
\hline $10 \quad 7$ & Location 7 & 7 & 0.06 & 0.24 & 0 & 1 \\
\hline $10 \_8$ & Location 8 & 3 & 0.03 & 0.16 & 0 & 1 \\
\hline lo_other & Other Location & 1 & 0.01 & 0.09 & 0 & 1 \\
\hline protestant & Protestant & 94 & 0.85 & 0.36 & 0 & 1 \\
\hline catholic & Catholic & 6 & 0.05 & 0.23 & 0 & 1 \\
\hline muslim & Muslim & 8 & 0.07 & 0.26 & 0 & 1 \\
\hline rel_unknown & Unknown Religion & 3 & 0.03 & 0.16 & 0 & 1 \\
\hline group & Group & 7 & 0.06 & 0.24 & 0 & 1 \\
\hline retail_food & Business selling food & 45 & 0.41 & 0.49 & 0 & 1 \\
\hline retail_supplies & Business selling supplies & 40 & 0.36 & 0.48 & 0 & 1 \\
\hline animal husb & $\begin{array}{l}\text { Animal husbandry } \\
\text { business }\end{array}$ & 8 & 0.07 & 0.26 & 0 & 1 \\
\hline craftsman & Craftsman business & 3 & 0.03 & 0.16 & 0 & 1 \\
\hline farming & Farming business & 5 & 0.05 & 0.21 & 0 & 1 \\
\hline other busi & $\begin{array}{l}\text { Other business (solar } \\
\text { oven making) }\end{array}$ & 10 & 0.09 & 0.29 & 0 & 1 \\
\hline
\end{tabular}


Table 2

OLS Regression Output Summary

\begin{tabular}{|c|c|c|}
\hline Variables & Default Rate & SE \\
\hline clsd_oblmet & $-0.471 * * *$ & 0.0656 \\
\hline overpaid & $-0.469 * * *$ & 0.0746 \\
\hline active & $-0.239 * * *$ & 0.0693 \\
\hline lo_1 & $0.146^{*}$ & 0.0848 \\
\hline 1o_2 & 0.0381 & 0.0866 \\
\hline 1o_3 & 0.0733 & 0.0688 \\
\hline lo_4 & $0.269 * * *$ & 0.1020 \\
\hline $10 \_5$ & 0.147 & 0.1130 \\
\hline lo_6 & 0.0639 & 0.0805 \\
\hline lo_7 & -0.0566 & 0.1230 \\
\hline lo_other & -0.179 & 0.2010 \\
\hline protestant & 0.0746 & 0.0893 \\
\hline Muslim & $0.220 * *$ & 0.1030 \\
\hline rel_unknown & 0.180 & 0.1460 \\
\hline group & $0.232 * * *$ & 0.0762 \\
\hline retail_food & $-0.204 * *$ & 0.0822 \\
\hline retail_supplies & -0.117 & 0.0772 \\
\hline craftsman & -0.171 & 0.1370 \\
\hline farming & -0.124 & 0.1160 \\
\hline other_busi & $-0.169 *$ & 0.0942 \\
\hline Constant & $0.441 * * *$ & 0.1440 \\
\hline Observations & 111 & \\
\hline R-squared & 0.696 & \\
\hline
\end{tabular}

$* \mathrm{p}<.10{ }^{* *} \mathrm{p}<.05$. *** $\mathrm{p}<.01$. 
Table 3

Y-Consistency vs. Set Value

\begin{tabular}{lccccc}
\hline Set & Y Consist & Set Value & F & $p$ & NumBestFit \\
\hline 1. abde & .227 & .800 & 239.63 & $<.001$ & 75 \\
2. abdE & .381 & .800 & 13.53 & $<.001$ & 8 \\
4. abDe & .393 & .800 & 5.42 & .022 & 7 \\
3. aBde & .516 & .800 & 7.18 & .008 & 8 \\
\hline
\end{tabular}

Table 4

Conditions for a Low Default Rate

\begin{tabular}{ccccc}
\hline Path & Location 4 & Muslim & Group Loan & Other Business \\
\hline 1 & - & - & - & - \\
2 & - & - & - & Yes \\
3 & - & Yes & - & - \\
4 & - & - & Yes & - \\
\hline
\end{tabular}

